\title{
Transcriptional Profiles in the Chicken Ductus Arteriosus During Hatching
}

\author{
Satoko Shinjo, Toru Akaike, Eriko Ohmori, Ichige Kajimura, \\ Nobuhito Goda, and Susumu Minamisawa
}

\author{
Keywords \\ Ductus arteriosus $\cdot$ Microarray analysis $\cdot$ Chicken
}

The ductus arteriosus (DA) of oviparous animals differs from mammals' in the embryonic gas exchange system and its anatomy. We performed transcriptional analysis of chicken DA, attempting to elucidate the similarity and diversity in the mechanism of DA closure among species.

Chicken DA proximal to the pulmonary arteries (proximal DA) closes after hatching while the DA proximal to the aorta (distal DA) remains open even after hatching [1]. Histological analysis revealed that the ductal wall of the proximal DA became thicker with fragmented elastic fibers from embryonic day (ED) 19. Therefore, we performed microarray analysis with proximal DA, distal DA, and aorta from chicken embryo at ED19. Clustering analysis found that the expression pattern of distal DA was similar to that of proximal DA than that of aorta although

\footnotetext{
S. Shinjo $\cdot$ T. Akaike $\cdot$ I. Kajimura

Department of Cell Physiology, The Jikei University School of Medicine, Minato, Tokyo, Japan

E. Ohmori $\cdot$ S. Minamisawa $(\bowtie)$

Department of Cell Physiology, The Jikei University School of Medicine,

Minato, Tokyo, Japan

Department of Life Science and Medical Bioscience, School of Advanced Science and

Engineering, Waseda University, Shinjuku, Tokyo, Japan

e-mail: sminamis@jikei.ac.jp

N. Goda

Department of Life Science and Medical Bioscience, School of Advanced Science and

Engineering, Waseda University, Shinjuku, Tokyo, Japan
} 
distal DA has a similar structure to aorta. Subsequent pathway analysis with DAVID [2] revealed that proximal DA had enhanced expression of the melanogenetic genes compared with distal DA and aorta (Table 40.1). This result appears reasonable because proximal DA shares its developmental origin, neural crest, with melanocytes. Although several known genes such as transcription factor AP-2 beta (tfap2b) [3] were highly expressed in proximal and distal DA, we newly found proximalDA-dominant genes. Further investigation would be required to understand the role of these genes in DA closure not only for the chick but also for mammals.

Table 40.1 KEGG pathway analysis by DAVID from chicken DA microarray

\begin{tabular}{|c|c|c|c|c|}
\hline $\begin{array}{l}\text { Gene } \\
\text { symbol }\end{array}$ & Gene name & $\begin{array}{l}\text { Proximal } \\
\text { DA/aorta }\end{array}$ & $\begin{array}{l}\text { Distal } \\
\text { DA/aorta }\end{array}$ & Note \\
\hline \multicolumn{5}{|c|}{ Proximal DA dominant pathways } \\
\hline \multicolumn{5}{|c|}{ Melanogenesis/tyrosine metabolism } \\
\hline DCT & $\begin{array}{l}\text { Dopachrome tautomerase (dopachrome } \\
\text { delta-isomerase, tyrosine-related protein 2) }\end{array}$ & $1.44 *$ & 1.06 & \\
\hline EDNRB2 & Endothelin receptor B subtype 2 & $1.31 *$ & 1.07 & (1) \\
\hline TYR & Tyrosinase (oculocutaneous albinism IA) & $1.54 *$ & 0.94 & (1) \\
\hline TYRP1 & Tyrosinase-related protein 1 & $1.48 *$ & 1.03 & \\
\hline WNT11 & $\begin{array}{l}\text { Wingless-type MMTV integration site family, } \\
\text { member } 11\end{array}$ & $1.33 *$ & 1.14 & \\
\hline \multicolumn{5}{|c|}{ Arachidonic acid metabolism } \\
\hline CYP2C45 & Cytochrome P-450 2C45 & $1.44 *$ & 1.02 & \\
\hline HPGDS & Hematopoietic prostaglandin D synthase & $1.56 *$ & 1.02 & \\
\hline PTGS2 & $\begin{array}{l}\text { Prostaglandin-endoperoxide synthase } 2 \\
\text { (prostaglandin } \mathrm{G} / \mathrm{H} \text { synthase and } \\
\text { cyclooxygenase) }\end{array}$ & $1.31 *$ & 1.21 & \\
\hline \multicolumn{5}{|c|}{ DA dominant pathways } \\
\hline \multicolumn{5}{|c|}{ Focal adhesion/ECM-receptor interaction } \\
\hline FIGF & $\begin{array}{l}\text { c-fos-Induced growth factor (vascular endothelial } \\
\text { growth factor D) }\end{array}$ & $1.50 *$ & $1.29 *$ & (2) \\
\hline KDR & $\begin{array}{l}\text { Kinase insert domain receptor (a type III receptor } \\
\text { tyrosine kinase) }\end{array}$ & $1.34 *$ & $1.32 *$ & (2) \\
\hline LAMA4 & Laminin subunit alpha 4 & $1.33 *$ & 1.24 & \\
\hline LAMB1 & Laminin, beta 1 & $1.36 *$ & $1.27 *$ & \\
\hline TNC & Tenascin C & $2.15 *$ & $1.82 *$ & \\
\hline VWF & von Willebrand factor & $1.39 *$ & $1.31 *$ & \\
\hline CHAD & Chondroadherin & 1.24 & $1.22 *$ & \\
\hline ITGA1 & Integrin, alpha 1 & 1.28 & $1.21 *$ & \\
\hline \multicolumn{5}{|c|}{ VEGF signaling pathway } \\
\hline HSPB1 & Heat shock $27 \mathrm{kDa}$ protein 1 & $1.34 *$ & $1.21 *$ & \\
\hline KDR & $\begin{array}{l}\text { Kinase insert domain receptor (a type III receptor } \\
\text { tyrosine kinase) }\end{array}$ & $1.34 *$ & $1.32 *$ & \\
\hline PTGS2 & $\begin{array}{l}\text { Prostaglandin-endoperoxide synthase } 2 \\
\text { (prostaglandin G/H synthase and } \\
\text { cyclooxygenase) }\end{array}$ & $1.31 *$ & $1.21 *$ & \\
\hline PLCG2 & $\begin{array}{l}\text { Phospholipase C, gamma } 2 \\
\text { (phosphatidylinositol-specific) }\end{array}$ & 1.17 & $1.20 *$ & \\
\hline
\end{tabular}

The asterisk indicates that the component genes appeared in the result of DAVID analysis

(1) Only appeared in "melanogenesis,"

(2) Only appeared in "focal adhesion" 
Acknowledgment This work was supported by grants from the Ministry of Education, Culture, Sports, Science and Technology of Japan (T.A., S.M.), MEXT-Supported Program for the Strategic Research Foundation at Private Universities (S.M.), the Vehicle Racing Commemorative Foundation (S.M.), The Jikei University Graduate Research Fund (S.M.), and the Miyata Cardiology Research Promotion Foundation (S.M.).

\section{References}

1. Belanger C, Copeland J, et al. Morphological changes in the chicken ductus arteriosi during closure at hatching. Anat Rec (Hoboken). 2008;291:1007-15. https://doi.org/10.1002/ ar.20720.

2. Huang da W, Sherman BT, et al. Systematic and integrative analysis of large gene lists using DAVID bioinformatics resources. Nat Protoc. 2009;4:44-57. https://doi.org/10.1038/ nprot.2008.211.

3. Zhao F, Bosserhoff AK, et al. A heart-hand syndrome gene: Tfap2b plays a critical role in the development and remodeling of mouse ductus arteriosus and limb patterning. PLoS One. 2011;6:e22908. https://doi.org/10.1371/journal.pone.0022908.

Open Access This chapter is licensed under the terms of the Creative Commons Attribution 4.0 International License (http://creativecommons.org/licenses/by/4.0/), which permits use, sharing, adaptation, distribution and reproduction in any medium or format, as long as you give appropriate credit to the original author(s) and the source, provide a link to the Creative Commons license and indicate if changes were made.

The images or other third party material in this chapter are included in the chapter's Creative Commons license, unless indicated otherwise in a credit line to the material. If material is not included in the chapter's Creative Commons license and your intended use is not permitted by statutory regulation or exceeds the permitted use, you will need to obtain permission directly from the copyright holder.

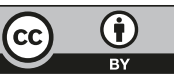

